\title{
Assim beijava Benjamin
}

\author{
José Lima Júnior*
}

\section{Resumo}

O artigo procura destacar uma forma de escrever usada por Rubem Alves. A maneira literária de transmitir pensamentos filosóficos, teológicos, sociológicos, pedagógicos e éticos aparece nos escritos do autor, especialmente a partir de 1983. O artigo faz uma análise e alguns comentários sobre o livro "Perguntaram-me se acredito em Deus", publicado em 2007. Essa obra de Rubem Alves é uma compilação de vários textos já publicados, adicionados alguns novos e apresentando o personagem Benjamin - uma espécie de alter ego do escritor.

Palavras-chave: Rubem Alves. Linguagem. Literatura. Vida. Benjamin.

\section{Thus kissed Benjamin}

\section{Abstract}

The article seeks to highlight a form of writing used by Rubem Alves. The literary way of transmitting philosophical, theological, sociological, pedagogical and ethical thoughts appears in the writings of the author especially since 1983. The article makes an analysis and some comments on the book "They asked me if I believe in God", published in 2007. This work of Rubem Alves is a compilation of various texts previously published, added some new and featuring the character Benjamin - a kind of writer's alter ego. Key-words: Rubem Alves. Language. Literature. Life. Benjamin.

\section{Así besaba Benjamin}

\section{Resumen}

El artículo pretende destacar una forma de escritura utilizado por Rubem Alves. La forma literaria para transmitir pensamientos filosóficos, teológicos, sociológicos, pedagógicos y éticos aparece en los escritos del autor, especialmente a partir de 1983. El artículo hace un análisis y algunos comentarios sobre el libro "Me preguntaron si yo

* Doutor em Comunicação e Semiótica. Professor na UNIMEP. joselimajunior22@gmail.com. 
creo en Dios", publicado en 2007. Esta obra de Rubem Alves es una recopilación de varios textos publicados anteriormente, agregados algunos nuevos y presentando el carácter Benjamin - una especie de alter-ego del escritor.

Palabras clave: Rubem Alves. Lenguaje. Literatura. Vida. Benjamin.

Os deuses são símbolos e artifícios do poeta. Zaratustra (NIETZSCHE, 2009, p. 174)

\section{Preliminares meio reticentes}

Quando um discurso sobre Deus chega à tênue e específica fronteira estética entre comunicação e expressão, a teologia roça a poesia... A propósito, ao falar da função poética, Roman Jakobson é bastante catedrático, conceituando-a "como o pendor (Einstellung) para a mensagem como tal, [ou seja] o enfoque da mensagem por ela própria” (1969, p. 127-128). Além disso, o semioticista russo é categórico: "Qualquer tentativa de reduzir a esfera da função poética à poesia ou de confinar a poesia à função poética seria uma simplificação excessiva e enganadora" (1969, p. 128). E ainda, perguntando-se a respeito do critério linguístico empírico da função poética (que, salvo melhor juízo, também se poderia chamar função estética), Jakobson responde: "a função poética projeta o princípio de equivalência do eixo de seleção sobre o eixo de combinação” (1969, p. 130). Um movimento instigante entre sintaxes e semânticas...

Trazendo tal perspectiva para o cenário deste dossiê, quero destacar como a forma espelha o conteúdo no discurso do último Rubem Alves...; no caso, uma escrita em que surge um "estranho" recaimento do significado no próprio significante...; uma textura da espiritualidade em que a linguagem fica sob a tensão do “equilíbrio embaraçoso” (DELAS \& FILLIOLET, 1975, p. 51). Por óbvio, os enfoques poéticos desse Rubem crepuscular ${ }^{2}$ são construídos criteriosa e criticamente nos interstícios das diversas teologias (sistemática, carismática, catequética, ritualística, apologética...); porém, seu lugar mais apropriado como texto-e-discurso talvez seja nos cultos e serviços devocionais...

Chalhub, Funções da Linguagem, p. 38. O admirável espanto provocado pelo bem-dizer poético é o que os formalistas russos chamaram de ostrânienie, "estranhamento".

2 Rubem Alves (1933-2014) viveu seu período de formação, da infância até o bacharelado em teologia (1933-1957); depois desenvolveu seu pastorado até o doutoramento em filosofia (1958-1968); atuou na academia universitária (1969-1990), e como psicanalista (1990-1997). Suas publicações começaram em 1969 e seguiram até 2014. As obras de caráter mais literário aconteceram entre 1983 e 2014 - esse o Rubem crepuscular. 
Essa poética (poiesis) da religião não se esgota no seu resultado, no produto criado; afirma-se, bem mais e melhor na cerimônia pública ou particular, como processo mesmo de produção, enquanto tal, no seu durante... Também não se fecha em si, pois seu elemento estético (aisthesis) se oferece aos sentidos corpóreos de cada pessoa e da comunidade... E por conta de sua maneira inédita de representar (mimesis), potencializa um conhecimento esclarecedor (katharsis) que se espraia pelo existir concreto e histórico... Enfim, com efetiva construção de sentido por parte de quem recebe a mensagem e dela se apropria ressignificando-a ao sabor de um saber, essa pnêumica rubeniana de perfil poético do discurso sobre Deus parece melhor desenhada para as teologias litúrgico-eucarísticas...

\section{Privilegiando intimidades}

Todo pesquisador sabe que a ciência precisa delimitar como objeto de estudo algum fenômeno específico, tangível e ao alcance de outros empreendimentos epistemológicos. Tal delimitação pode e deve ser livre, isenta (ao máximo possível) de determinações que comprometam a frágil e relativa autonomia da prática científica. Anterior à pesquisa de fato, portanto, acontece um ato de vontade - a livre delimitação de um objeto para submetê-lo a um método também eleito como preferível. No caso deste artigo, tomei apenas um livro de Rubem Alves - Perguntaram-me se acredito em Deus ${ }^{3}$ - para analisar alguns de seus detalhes e repartir um ligeiro ensaio com meia dúzia de considerações.

Sem dúvida, contraposta à minha escolha, paira enorme suspeita diante das publicações rubenianas que deixei preteridas. ${ }^{4}$ Em outras palavras, por que esse livro e não tantos outros para um exercício sobre a poética da religião em Rubem Alves? As respostas (por um lado, claramente desnecessárias; e, por outro, meio inócuas) privilegiam intimidades.

Aponto como característica que realça o reservado, o íntimo..., um primeiro item: Perguntaram-me se acredito em Deus é título fruto de uma indagação feita em público por uma senhora ao Rubem. Imagino que a pergunta pretendia adentrar o âmago da subjetividade do autor que participava de um debate sobre educação promovido pelo jornal Folha de S. Paulo, em março de 2007. A pergunta soa, portanto, em tom quase invasivo, meio indiscreto, beirando figurar como desafio a uma exposição constrangedora. De qualquer modo, admito ser um título inusitado e, portanto, mercadológico - para dizer o mínimo.

Primeira edição publicada pela Planeta do Brasil (SP), em 2007.

4 Entre teologia, filosofia, sociologia, educação, biografia, ética e literatura, Rubem Alves publicou mais de 150 livros. 
A publicação desse livro, em 2007, é antecedida por situações densas e sobremodo tensas na vida de Rubem Alves. Isso também tangencia outras intimidades, ainda que indiretamente - afinal, amiúde expressões verbais funcionam como indícios das entrelinhas da existência. Suponho como dolorosa moldura para esse livro importantes acontecimentos relacionados à saúde física e ao redemoinho emocional que envolveram Rubem desde aprazíveis desfrutes até agudos contratempos no ano anterior ao lançamento da obra. Uma breve consulta à sua biografia $a^{5}$ é o suficiente para considerar plausível a minha hipótese, a partir de três fatos. Em meados de 2006, o autor termina seu relacionamento com Thais Couto (iniciado em 1996, ${ }^{6}$ quando se divorciara de Lídia Nopper); descobre um câncer no estômago que o obriga a uma cirurgia; e reata com Thais ao final desse mesmo ano de 2006.

\section{Sussurros ao pé do ouvido}

Já na orelha da capa do Perguntaram-me se acredito em Deus começam as tentações voltadas para a sedução de leitores e leitoras. A estratégia aplicada implica estabelecer um campo comum - evocar e exibir uma cumplicidade de gosto, uma coincidência estética, uma comunhão de julgamento: quem escreve e quem lê correm o risco de se descobrirem contaminados por um mesmo tecido orgânico, uma mesma textura de linguagem, um mesmo texto-livro.

Essa tentativa/tentação talvez não obtivesse sucesso caso fosse produzida, sendo a racionalidade o fator exclusivo e mais exibido. Igual fracasso poderia ocorrer se o assunto, como referencial, imperasse absoluto e sem equívocos portando uma verdade indubitável, clara e distinta. Contudo, a concretude corpórea sabe e saboreia muito bem uma descoberta ainda mais inquestionável: sussurros combinam mais com razões do coração: sugestões que emocionam o pensamento: palavras e silêncios poéticos. Há que se instaurar, portanto, um clima impactante, sobrenatural, extraordinário - o que efetivamente Rubem Alves consegue em quatro pequenos parágrafos carregados de insinuações que muito parecem uma sutil e elegante "cantada" ao pé do ouvido:

\footnotetext{
5 Nesse caso usei, pelo menos, duas fontes: O site do Instituto Rubem Alves, acessado várias vezes ao final de 2016 e início de 2017 (http://www.institutorubemalves.org.br/rubem-alves/ tempus-fugit/biografia/). Também li, nesse período, o livro É uma pena não viver - uma biografia de Rubem Alves, escrito pelo jornalista e pesquisador Gonçalo Júnior.

6 Quanto a essa data, há discrepância entre as fontes. No site do Instituto Rubem Alves, a data é 1994.
} 
Escrever e ler são rituais mágicos. Num primeiro momento, aquele que escreve transforma a sua carne e o seu sangue em palavras. No momento seguinte, aquele que lê transforma as palavras lidas na sua própria carne e no seu próprio sangue. A isso se dá o nome de antropofagia. O escritor se oferece para ser comido. O leitor lerá o texto se o seu gosto for bom. Se o gosto do texto for bom, ele então o comerá até o fim. Escrever e ler, assim, são um ritual eucarístico: comer carne e beber sangue. O sangue do escritor então irá circular no corpo daquele que o leu.

Os rituais antropofágicos não se faziam por razões gastronômicas. O que se desejava era que as virtudes da vítima fossem transferidas para o corpo daquele que comia.

Estes textos são pedaços de mim. Li muitos textos sagrados. Comi aqueles que me deram prazer. Os outros, meu sangue os rejeitou.

Agora eu os ofereço como partes de mim mesmo. Se eles lhe derem prazer, você ficará parecido comigo. E experimentaremos aquilo a que se dá o nome de comunhão... (2007, íntegra do texto na orelha da capa).

\section{Declaração de afeto}

Para o John Lane, amigo - eis a dedicatória (ALVES, 2007, p. 5). De maneira direta, singela e condensada, essas cinco palavras sugerem traduzir o belo e profundo sentimento do autor - consciente, a meu juízo, de seu sentimento ser irredutível ao verbo. Mesmo linguisticamente minimalista, a frase indica um carinho de máxima grandeza - e isso atesta, com plena convicção, quem conheceu a amizade entre eles. O agraciado pela declaração de afeto, John Cook Lane, é pessoa rara, digna do adjetivo que mais caracteriza o ser: humano.

Muitos foram os pontos em comum entre John e Rubem - por sinal, vizinhos por longos anos quando moraram próximos ao Seminário Presbiteriano do Sul, em Campinas. Ambos mineiros. John, natural de São Sebastião do Paraíso, 1928. Rubem, nascido em Boa Esperança, 1933. Repartiram afinidades e angústias tanto oriundas de fatos quanto decorrentes de interpretações. Em todo caso, acima de qualquer dúvida, o amor pelas árvores está na raiz dessa amizade.

Neto e filho de missionários presbiterianos, John tornou-se médico cirurgião de importância internacional e cidadão de relevância ímpar nos menores detalhes - aqueles que fazem toda a diferença. John foi pioneiro no Brasil divulgando a técnica da reanimação cardiorrespiratório-cerebral. Ministrou centenas de cursos de extensão universitária nos Estados Unidos, China, Argentina, Chile, Peru e Brasil. Foi eleito duas vezes como governador para o Brasil pela American College of Surgeons e uma vez pela American Academy of Chest Physicians and Surgeons. Em Campinas fundou, com seu irmão Eduardo, a Clínica Lane e o Centro Mé- 
dico de Campinas - um hospital de referência, com sua Escola para Auxiliares em Enfermagem, com o apoio da UNICAMP. ${ }^{7}$ Ainda em 2017, ano da escrita deste artigo, John Lane continua com sua participação na sociedade escrevendo livros e artigos sobre variados assuntos, sempre sublinhando sua aposta na vida.

\section{Exposição dorsal}

Precedendo o sumário de Perguntaram-me se acredito em Deus, há um texto em diagramação centralizada que revela as entranhas de uma confissão do autor. Esse desnudamento, porque poético, tem força e disfarça. Rubem diz sem falar. Quem apenas escuta suas palavras quase não consegue ouvir outro e maior discurso de eloquência brejeira e evasiva. Também aqui o significante isolado não garante o significado mais complexo. Portanto, uma leitura das entrelinhas se impõe. Isto é, faz-se imprescindível uma hermenêutica muito ventosa, a partir de uma exegese bastante imprecisa... E com isso (de novo e apesar disso) a obra sobrevive ao escritor.

Perguntaram-me se acredito em Deus.

Respondi com versos do Chico:

"Saudade é o revés do parto.

É arrumar o quarto do filho que já morreu."

Qual é a mãe que mais ama?

A que arruma o quarto para o filho que vai voltar ou a que arruma o quarto para o filho que não vai voltar?

Sou um construtor de altares.

Construo altares à beira de um abismo escuro e silencioso.

Eu os construo com poesia e música.

Os fogos que neles acendo iluminam o meu rosto e me aquecem.

Mas o abismo permanece escuro e silencioso.

$$
\text { (ALVES, 2007, p. 7) }
$$

A exposição que Rubem Alves oferece de si mesmo não é frontal. Diante da pergunta sobre a crença em Deus - pergunta grávida de expectações consoladoras ou de julgamentos onerosos - o autor responde como que virando sugestivamente as costas. Certo é que não foge à questão, contudo, retoma-a quase pelo avesso. Bem oposto a um repugnante contraponto de enfrentamento (que escorregaria irresponsavelmente para manipulação, desqualificação ou embromação), a saída

7 Mais informações sobre John Lane, ver http://clinicalane.com.br/clinica.php (acessos em fev. 2017). 
rubeniana é mais agradável e mostra seu dorso; é um convite para o interlocutor penetrar-lhe..., e olhar o horizonte do inquérito com os olhos do questionado.

Rubem, então, lembra sua réplica amigável: Respondi com os versos do Chico. E assim o autor faz do desvio, com o desvio e no próprio desvio um atalho para uma intimidade que desarma, acenando para uma pacificação empática. Rubem pinça um trecho da canção Pedaço de mim, composta para a personagem Teresinha, filha de Duran (dono de bordéis na noite carioca dos anos 1940), namorada de Max Overseas (contrabandista e rival de Duran). Esses personagens fazem parte da peça musical Ópera do Malandro, composta por Chico Buarque em 1978. A canção é apresentada no momento em que Teresinha está terminando sua visita a Max na cadeia. Como tantas outras composições de Chico, Pedaço de mim passou a ser apreciada independente de seu contexto original ${ }^{8} \mathrm{~A}$ angústia do despedaçamento do eu reapresentado na canção recobriu a dor da perda (em suas múltiplas ocorrências), com tamanha precisão lógica e riqueza metafórica, que atinge certa universalidade. E o próprio Rubem, assim, assume indiretamente sua perda: Deus. ${ }^{9}$

Se o autor tivesse respondido positiva ou negativamente à pergunta daquela senhora no debate da Folha, iria apenas confirmar ou não uma crença, sem considerar a real existência ou a efetiva ilusão desse objeto de crença. Por isso, a resposta de Rubem Alves por meio de uma citação poética ultrapassa a literalidade e acessa o simbólico: saudade é o revés do parto; é arrumar o quarto do filho que já morreu. Quem sabe, então, Rubem esteja admitindo suas saudades de Deus - morto assim como nasceu: desejo-de-sentido-último-e-absoluto. Símbolo e Poesia. ${ }^{10}$

E Rubem acrescenta outra qualificação ao seu caso perdido: construtor de altares. Sua matéria-prima, suas ferramentas e seus projetos são poesia e música arte. Deixou de ser teólogo. O privilégio da racionalidade mostrou-se impróprio

8 Vale a pena conferir um vídeo dessa canção com as vozes de Zizi Possi e Chico Buarque, em 1978: https://www.youtube.com/watch?v=nRNmIumFui8 (acesso em fev. 2017).

9 Em outra obra, O quarto do mistério (1995), Rubem Alves chama Chico Buarque de teólogo brasileiro e cita a mesma frase: "Saudade é o revés do parto, é arrumar o quarto para [sic] o filho que já morreu". E termina o parágrafo alertando: "Os que mais amam a Deus são os que não acreditam que ele existe e, a despeito disso, continuam a ter saudades dele..." (op. cit. p. 172). Especificamente essas palavras fazem parte de uma entrevista concedida a Paulo Nogueira, em 1994, e publicada pela Revista NOTAS 2.

10 Em outra passagem dessa mesma obra já citada, O quarto do mistério, encontramos mais um comentário sobre símbolo: "há símbolos que são diferentes. Porque ao invés de morarem em nossas cabeças, somos nós que moramos neles. Jogo de palavras, impossível em português: instead of understanding the symbols, what matters is standing under them... Perguntam-me se acredito nos meus símbolos religiosos. Por que não me perguntam se acredito em meus símbolos poéticos?” (op. cit. p. 90-91). 
e infeliz na abordagem do divino. Divindade agora parecendo um abismo escuro e silencioso - outro modo de dizer um quarto vazio do filho já morto. E os fogos acesos nesses altares nada mais conseguem senão iluminar e aquecer seu construtor, posto que o abismo-antes-nomeado-deus não se altera em seu silêncio e obscuridade. Em suma: cura e conforto pela mediação artística.

\section{Psiu! veja bem... o negócio é o seguinte:}

Ainda em termos prefaciais, o que figura como primeiro capítulo (dos 22) do Perguntaram-me se acredito em Deus chama-se Explicação. Mais explícito impossível. Cumpre o papel de colocação de balizas para uma leitura adequada aos propósitos do autor. Chega mesmo a ser uma espécie de complementação, uma justificativa mais detalhada ao que ficou dorsalmente exposto.

Cometendo um lamentável enxugamento, meu árido resumo dessa explicação pouco dá conta como Rubem deságua suas considerações: mosaicos são feitos de cacos; músicas são mosaicos de sons; o ser humano é um mosaico de acontecimentos; as Escrituras Sagradas são mosaicos de estórias... O autor também lembra que as estórias nunca aconteceram e por isso estão sempre presentes, vivas, "emissárias da eternidade". Daí seu alerta: tornar a estória história equivale a uma perda; porque realmente acontecida no passado, a "história é criatura do tempo", não incorpora mais. E assim Rubem termina sua explicação com transparência e serenidade: "Escolhi os cacos de que mais gosto para fazer o meu mosaico, o meu livro de estórias, a minha sonata, o meu altar à beira do abismo" (2007, p. 17).

\section{O nome que ousa dizer seu amor}

Nos demais 21 capítulos, Rubem Alves passa a palavra ao Mestre Benjamin. Ficam implícitas as simpatias entre Mestre Benjamin e o contador de parábolas que viveu na Palestina milênios atrás. Também notórias são as paráfrases que Rubem traz de passagens da tradição hebraica. Porém, como o desejo de Rubem é recuperar o viço da oralidade e seu peculiar apelo à presentidade reinventiva (quem conta um conto aumenta um ponto), a alusão a Jesus (Senhor das Estórias) e aos poetas et profetas que lhe foram anteriores é uma alusão subversiva - versa por baixo, solapando "historicidades" e reinventado o eterno-em-cada-caco. Conforme Rubem Alves, o Mestre Benjamin "era um contador de estórias. Todos o amavam, especialmente as crianças que adoravam fazer perguntas. Sabem por que? Porque, em vez de dar respostas às perguntas, ele inventava estórias...” (2007, p. 22).

Mas de onde Rubem tirou esse Benjamin? Dar uma resposta seria pouco benjaminiano e Rubem não perdeu a chance para forjar um arremedo de estória. 
Em Belo Horizonte, no Palácio das Artes, participando do programa Sempre um papo $(20 / 8 / 2007)^{11}$ a respeito desse livro recém-lançado, o escritor desconversa com a maior naturalidade: "não me perguntem por que eu escolhi esse nome [Benjamin]. Eu não sei”. Minutos depois completa: "eu diria que escrevi esse livro para crianças. Acho que de alguma maneira eu me identifiquei com o Mestre Benjamin".

Se essa identificação deixa em aberto suas razões, fico mais livre para inventar estórias em torno desse Benjamin rubeniano. Assim, projeto três hipóteses não excludentes. Talvez, complementares. Melhor dizendo, sem muito rigor, meio à moda de uma psicanálise de almanaque, essas hipóteses recobrem uma respeitosa e carinhosa brincadeira com a memória de Rubem Alves, a partir das categorias freudianas id, ego e superego (em ordem inversa). Mais não esclareço, senão estrago completamente esse jogo. Apenas peço aos leitores um pouco de seu humor benevolente diante de experiências graves e sérias vividas pelo autor.

Em 1945, a família de Rubem Alves, buscando recuperar-se de uma falência econômica, saiu das Minas Gerais e se estabeleceu na capital do país, Rio de Janeiro. $\mathrm{O}$ adolescente conheceu então o mar e, também..., o mar (equivalente no sotaque mineiro a mal). A maldade lhe aportou à margem das ruas, ancorada justo na escola, no recreio, na educação... Rubem começou assim seu infeliz desembarque como pária na pátria das comparações - essa imensa, ingrata e impiedosa terra dos malefícios. Diferente dos colegas um tanto elitizados do Colégio Andrews, o jeito caipira de falar e a condição de menino pobre trouxeram para Rubem desconforto desde o primeiro dia de aula. Constantemente, sofria provocações e zombarias. Tomou consciência que era mais pobre do que supunha; soube e sentiu que também estava apodrecendo sua inocente e ingênua felicidade. E um episódio ficou profundamente marcado em Rubem, por causa de um colega chamado Benjamin. Segundo as palavras do próprio Rubem, esse Benjamin "estufava feito um sapo, cheio de gabolices” (GONÇALO JÚNIOR, 2015, p. 119). Na única vez em que dirigiu a palavra a Rubem, Benjamin disse apenas: "você é ridículo" (GONÇALO JÚNIOR, 2015, p. 120). Isso deixou o adolescente magoado e arrasado até as entranhas. O estrago foi tamanho que muitas décadas depois, já iniciando o seu doutorado em Princeton, Rubem recolocou em questão suas crenças religiosas protestantes de juventude, relacionando-as ao veredito do colega cruel: "Benjamin estava certo. Eu era ridículo. Mas não pelas razões dele - que eu era ridículo por ser caipira de Minas, que falava os erres torcendo a língua. Sou ridículo pelas ideias em que acreditei” (GONÇALO JÚNIOR, 2015, p. 163, 241). É possível, portan-

11 Conforme https://www.youtube.com/watch?v=xjJB3rHK9PE (acessado em 26 jan. 2017).

As palavras de Rubem Alves aqui citadas ocorrem aos 37 e 42 minutos no vídeo. 
to, imaginar um eventual vínculo suprafactual, plurifenomênico, com aberturas polissêmicas de superação valorativa, capaz de ressignificar determinado nome e determinada condição. Do Benjamin histórico que inventou um Rubem ridículo..., ao Benjamin que Rubem inventa nas estórias que transcendem suas crenças ridículas.

Outra hipótese sobre a escolha de Rubem Alves nomeando Benjamin quero aventar a partir do nascimento de sua filha Raquel em 10 de novembro de 1975. Rubem e Lídia já tinham dois filhos: Sergio, com 16 anos, e Marcos, com 13 anos de idade. Tanto essa gravidez quanto o parto transcorreram muito tranquilos, porém um problema congênito (só percebido no parto, acontecido em época anterior à ultrassonografia), alterou Rubem completamente: a nenê apresentava lábio leporino e fissura palatal a prejudicar a respiração (GONÇALO JÚNIOR, 2015, p. 274, 275). A partir desse instante, muitas cirurgias se sucederam, muitos desafios foram enfrentados e superados, muita história se transubstanciou em estórias. Já em 26 de março de 1978, Rubem deixava registrado em uma carta à filha: "Quando uma criança nasce forte e perfeita, ela não sabe direito o que é a vida. Mas quando a vida é conquistada palmo a palmo, ela fica linda". E emenda uma confissão: "Estou escrevendo para dizer obrigado, Raquelzinha. O seu amor pela vida está me ajudando a viver. Você é mais sábia do que eu". E ao final da carta, constata e aconselha: "Depois que você nasceu, a vida ficou diferente. Quando você crescer leia o Pequeno Príncipe e você entenderá o que estou dizendo, Estrelinha Falante" (GONÇALO JÚNIOR, 2015, p. 278, 280). O recurso à fábula foi a saída privilegiada por Rubem para traduzir o inefável. Surgia um novo Rubem poiético desde seu fruto genético. Um Rubem até então não assumido, não editado, não reconhecido. Não mais apenas um teólogo, um filósofo, um escritor, um acadêmico em suas reflexões e comunicações para adultos. Esse novo Rubem começou a revestir todo seu vasto repertório cultural com uma linguagem que pudesse alcançar o coraçãozinho da filha mais admirada e mais amada. ${ }^{12} \mathrm{E}$ assim Rubem começou a criar estórias e mais estórias para se comunicar com Raquel. Ou seja, a realidade da filha gestou no pai um inventor de fábulas, um escritor de fantasias, um poeta para crianças. E parece-me interessante nesses fatos uma coincidência: na tradição hebraica, a matriarca Raquel - esposa predileta de Jacó - deu à luz seu segundo filho (e último de Jacó), chamado Benjamin. ${ }^{13}$ Por isso, talvez,

12 Hoje, 2017, Raquel é reconhecida arquiteta, paisagista e decoradora. Também preside o Instituto Rubem Alves.

13 No livro das Gênesis, a partir do capítulo 29, lemos que Jacó se casou com duas mulheres: Lia e Raquel. Com Lia teve seis filhos, sendo o primogênito Rubem. 
numa repaginação contemporânea, Raquel Alves fez nascer outro Benjamin, esse outro Rubem Alves. Aliás, o nome Rubem em hebraico significa eis ai o filho. $\mathrm{E}$ assim, o pastor Rubenjamin foi guiado e guardado pela ovelhinha Raquel todos os demais dias da sua vida...

Uma terceira hipótese em torno do nome desse Benjamin escorrega pelos desvãos hermenêuticos advindos da convivência que tive com o autor. Admito estar minha hipótese demarcada, sulcada, entalhada por discutível subjetividade, ainda que sob o cinzel da concretude objetiva do cotidiano. Foram muitas as vezes que dele ouvi referências a momentos de êxtases e de angústias relativos à década que precedeu à publicação desse Perguntaram-me se acredito em Deus. Esses momentos compreendiam e comprimiam o bumano, mui siderado bumano Rubem - um homem novamente apaixonado. Uma paixão à moda de Pedro Abelardo \& Heloisa - paradigma dos amantes desde o século XII. Assim, esse nome Benjamin me reverbera mais que seu significado; ${ }^{14}$ é um significante com gosto de trocadilho - quase um lapso verbal em toada caipira desafi(n)ante: beija mim. Arrisco imaginar outros signos espocando símbolos outros oriundos do íntimo rubeniano naqueles dias e noites entre 1996 e 2006: beija-me porque sonho e posso...; beija-me porque sinto e roço...; beija-me porque sofro e gozo...; intonce, beija mim; beija mim, nai; beija mim, sô, pra ponhá mai sustança no coiso, pra mór de aprumá o forfé qui veve meu coração. E retomando a primeira orelha do livro para uma releitura seletiva (interesseira e suspeita), passo a combinar um trecho com o que Rubem expressa nas últimas linhas da contracapa desse mesmo livro. No contexto da antropofagia cultural o escritor se oferece para ser comido e isso exponencia o valor que Rubem dá à existência: "Gostaria de viver muito porque a vida é boa". Ou seja, ele queria ser bem comido, comido tão gostosamente quanto gostosa era a maneira dele apreciar a vida. Seu apetite existencial era pleno e, igualmente, sua oferenda no altar das letras. E como transubstanciação de sua carne em livro, afirmava: "escrevo pela alegria de escrever e, acho, para continuar a viver, mesmo quando estiver ausente". Por certo, sua ideia de sobrevida não comungava com crenças e metafísicas tradicionais. Tratava-se de outra postura: "sou místico, embora jamais tenha visto anjos azuis. Meu Deus é a beleza". E em nome dessa divindade Rubem escrevia desejoso de ser beijado, comido, perenizado com os cacos de beleza que compunha. Pois "este livro é um fragmento do meu misticismo herético (e erótico)". Portanto, Rubem mesmo, ipsis litteris, não deixa dúvida quanto à eroticidade presente em sua obra estoriada por seu alter ego Benjamin.

14 Etimologicamente, Benjamin (nome de origem hebraica) significa filho de minha mão direita, conotando felicidade. 


\section{Variações de um affair}

- Diga-me com quem conversas e dir-te-ei se dormirás comigo.

Um intercurso dialogante depende das vozes que se provocam; com a própria língua ou deliciosamente apropriada. Sherazade que o confirme ou emudeça. E nesse caso, o harém do Mestre Benjamin se mostra diversificado; tão diverso e variado que me dediquei a inventariar citações explícitas ou implícitas nesse Perguntaram-me se acredito em Deus. Tal inventário (passível de acréscimos e reparos) pretende apenas indicar as páginas no conjunto de quase todos os autores usados por Rubem Alves para as estórias de Benjamin - como se esse Benjamin fosse leitor e parafraseador de Adélia Prado (p. 48); Ângelus Silesius (p. 46); Cântico dos Cânticos (p. 33); Cecília Meireles (p. 21, 25); Coríntios, epístola (p. 167); Eclesiastes (p. 57, 160, 162, 170); Emily Dickinson (p. 27); Ezequiel (p. 77); Fernando Pessoa e heterônimos (p. 31, 54, 58, 93); Gênesis (p. 45, 64); Habacuque (p. 78); Helena Kolody (p. 26); Isaías (p. 84-86); Jesus, o Senhor das estórias (p. 15, 102, 109, 115, 121, 129, 135, 141, 147, 153, 160); João, epístola (p. 169); João, evangelista (p. 23); Mário Quintana (p. 84); Milan Kundera (p. 15); Nietzsche (p. 87); Pascal (p. 22); Paul Valéry (p. 83); Provérbios (p. 160); Ravel (p. 15, 31); Robert Frost (p. 173); Salmos (p. 39, 72, 159); Tiago, epístola (p. 56); Walt Whitman (p. 40, 46, 57); William Blake (p. 47).

Escravos de Jó jogavam caxangá. Tira, põe, deixa ficar... A tonga da mironga do kabuletê...

De igual modo, também me parece útil transcrever o sumário dos capítulos dessa obra: Explicação. No princípio, o jardim. O abraço de amor. A alma. A inveja. Deus e a beleza. A arca de Noé. A tranquilidade das ovelhas. A ressurreição. A esperança. $O$ Deus criança. Sem débitos e sem créditos. O travesti e os religiosos. O homem sem pecados e a prostituta. Os jardins e as pedreiras. O rico que não tinha sabedoria. Pureza de coração é amar uma só coisa. Vivendo a vida como as crianças vivem. Sobre a felicidade. Sobre a oração. A sabedoria. Brumas e espumas (ALVES, 2007, p. 9-10). Conforme o próprio Rubem avisou, esses capítulos são cacos, fragmentos... E isso me leva a pensar que sua organização pode ser alterada ao alvitre do artista na composição de seu mosaico. Talvez excetuados apenas três capítulos (Explicação - já comentado; No princípio, o jardim - que abre a montagem/moldura para o Mestre Benjamin; e o último, Brumas e espumas) os demais poderiam mudar de posição sem grande pre- 
juízo dessa arte rubeniana. De uma forma ou de outra, o que enquadro a seguir é um pequeno (bem pequeno) conjunto de trechos em que Rubem corporifica Benjamin por meio da materialidade da palavra. Isso corresponde ao maior acento sobre o significante, desvencilhando-o da mera instrumentalização por parte do significado. Ficam sublinhados os sons e seus sinais, compondo concretamente os conceitos. Ou, melhor dizendo, os conceitos são aprofundados precisamente na sonoridade das palavras, nos paradoxos entre as intenções e as enunciações, nas omissões e nos silêncios... A mensagem é melhor constituída em sua própria embalagem. O que se diz é o como é dito.

\section{Assim beijava Benjamin...}

Beijava com sua aparência de ancião cheio de charme. Em atropelamento ao modernoso culto à virilidade juvenil, geralmente oca, insossa e descartável, o Benjamin de Rubem Alves comparece como galã das ultrapassagens sempre modernas; tipo me-leva-pra-casa, sugerindo o terno conceito me põe no colo:

Mestre Benjamin fez silêncio. Seus olhos ficaram semicerrados, como se estivesse tentando ver algo que ninguém via. Depois de alguns minutos começou a falar. Sua voz era quase um sussurro (2007, p. 23).

Mestre Benjamin era sábio. Ele sabia que há palavras depois das quais nenhuma outra palavra deve ser dita (2007, p. 41).

[...] seus olhos, já enrugados nos cantos pela idade, a longa cabeleira branca caindo sobre os seus ombros (2007, p. 63).

[...] já estava velho, muito embora se parecesse com uma criança. A longa barba branca, o andar vacilante, a visão curta, a surdez (2007, p. 167).

Beijava com alguns fonemas sibilantes, entremeados de nasais, registrando um exercício metalinguístico sobre o conceito do sussurro. Esse modo suave de elocução do personagem é descrito de igual modo. A forma já é o conteúdo confirmado. E assim retomo uma citação feita no parágrafo anterior, para agora sublinhar nasais e dar negrito e itálico para as sibilantes:

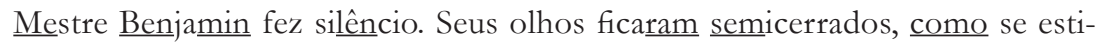
vesse tentando ver algo que ninguém via. Depois de alguns minutos começou a falar. Sua voz era quase um sussurro (2007, p. 23). 
Beijava com a vogal "e" fechada, surpreendendo com três ocorrências abertas, sendo a segunda mais destacada, bem na proparoxítona de "pétalas" - em contraponto a outra tônica desse tipo, na vogal "o", também aberta (estórias). Um exercício verbal do Mestre Benjamin sobre o conceito da pulsação sideral:

"Amanhã eu conto mais", ele disse, pondo fim à sessão de estórias.

Todos foram para suas casas $e$ sonharam que as estrelas eram borboletas nas pétalas das violetas do grande jardim do universo (2007, p. 27).

Beijava com o encadeamento de frases sem pontos, tudo sob vírgulas, como que apostrofando uma semântica a ecoar o abraço de amor divino. À semelhança do vaivém e do vira-revira de uma relação sexual, as frases se abraçam voluptuosamente. O trecho selecionado é antecedido por uma contextualização encharcada de liberdade apropriadora de cacos culturais. "Para espantar sua tristeza, Deus tomou a sua flauta e pôs-se a tocar. Era uma música que um compositor chamado Ravel iria compor muitos milênios depois. A música que Deus tocava se parecia com um caracol" (2007, 31). E Benjamin costura, então, um bolero de franjas da língua sobre o conceito da autoconsciência antropológico-teológica, via experiência erótico-lúdico-estética.

E esse caracol de sons foi enrolando tudo, tomando a forma de um homem e uma mulher que se abraçavam e se separavam, por vezes entravam um dentro do outro de tal forma que nem era possível saber qual era qual, e Deus entrou na dança, corpos nus, e achavam bonita a nudez porque eram crianças que brincavam uma com a outra, o corpo da mulher era brinquedo para o homem, o corpo do homem era brinquedo para a mulher, e de vez em quando eles desapareciam numa explosão de cores e perfumes, e Deus se viu refletido pela primeira vez nos olhos deles, duas crianças, homem e mulher... (2007, p. 32).

Beijava com uma série da letra "l", destacando-a para uma sequência de postes plantados para o conceito de luminosidade e orientação espacial. No contexto dos reis magos em busca da solução dos enigmas, Benjamin diz que esses sábios

...muito caminharam por areias brancas e desoladas. Até que viram ao longe o lugar que a luz da estrela iluminava. Era uma estrebaria, morada de animais. Bois, vacas, jumentos e ovehas estavam à volta do cocho onde o menininho dormia. As lâmpadas estavam apagadas porque milhares de vagalumes tudo iluminavam. Ao ver o menininho, eles riram de alegria, depuseram sua vehice ao lado da estrebaria e voltaram felizes para suas casas, correndo e pulando como crianças (2007, p. 92). 
Beijava com uma aliteração do "f" ao descrever como é feita a pipoca - metáfora da condição antropológica susceptível, sob linguagem poética, à beleza. Benjamin ilustra com isso o conceito da revolucionária atualização da bondade bumana pela potencialidade estética, apesar das pétreas maldades incrustradas. Um elogio à explosão provocada pelas fantasias:

O fogo só faz a flor sair para fora.... Assim somos nós. Temos grãos duros de pipoca na alma. Quando as estórias são contadas, os grãos de pipoca estouram e a flor que havia neles desabrocha para o lado de fora com um estouro! (2007, p. 95).

Beijava com paráfrases de trechos conhecidos, meticulosamente aplicados a situações adversas. Diante do medo, o Salmo 23 (O Senhor é o meu pastor...) recebe referência ao que faz as ovelhas mais temerem: o lobo. Nesse contexto, surge o conceito da coragem: dormir sem medo a despeito do perigo. E o capítulo termina descrevendo que as crianças que ouviram Mestre Benjamin voltaram para suas tendas e dormiram sem medo, mesmo ao som do uivo de algum lobo faminto. E desde então, revela Rubem Alves, tornou-se costume contar ovelhinhas para dormir (2007, p. 73). Outra paráfrase prenhe de poder profético me parece oportuna para uma transcrição na íntegra, especialmente devido ao seu tratamento do conceito de resiliência. O trecho é de Habacuque 3:17-18 (2007, p. 78):

Embora a seca seque as fontes e os rios, e os campos fiquem esturricados,

e o gado morra de sede e fome,

e as queimadas devorem os pastos,

e os machados transformem florestas verdes em desertos áridos,

e os palácios estejam cheios de corruptos -

A despeito disso minha alegria continuará a florir

e farei poemas diante do Impossível.

Beijava com algumas traduções poéticas. Verdadeiros achados. Criativos expedientes na difícil e rara tarefa de transpor signos entre sistemas de linguagens complexos por conta de seus textos\&contextos\&texturas. Diante do tão controverso Übermensch nietzschiano (traduzido como Super-Homem, Além-Homem, além-do-homem, além-do-bumano etc.). Benjamin nomeia esse conceito de superação reiterando, dando-lhe uma imagem de autossuperação contínua como "o homem transbordante" (2007, p. 87). Já para o famoso havel havalim do impressionante Coélet/Eclesiastes (traduzido desde vaidade das vaidades até névoa-nada), Benjamin 
reveste o conceito da fugacidade, do efêmero, do evanescente com o binômio "brumas e espumas" (2007, p. 170).

Beijava com leveza, desenvoltura e sem afetação, uma gama de variações sobre o conceito de Deus e seus atributos:

No Princípio, antes que qualquer coisa existisse, antes que houvesse o Universo, o que havia era a Poesia. Deus era Poesia. A poesia era Deus. Deus e a Poesia eram a mesma coisa. E Deus criou as estrelas para, com elas, escrever seus poemas nos céus... (Prólogo, Evangelho de João; paráfrase) (2007, p. 23).

E Deus, que tinha um rosto de criança, riu de felicidade e disse: "Que bom lugar para se morar, eternamente". E deixando para sempre o céu vazio passou a viver no jardim, brincando à brisa fresca da tarde. Árvores, regatos, flores, pássaros, borboletas, perfumes, cores, sons, nuvens, chuva, frutas: esses eram os brinquedos do Deus criança (2007, p. 26).

Deus é como o vento. Sentimos na pele quando ele passa, ouvimos a sua música nas folhas das árvores e o seu assobio nas gretas das portas. Mas não sabemos de onde vem nem para onde vai (2007, p. 54).

Deus é como um pássaro encantado que nunca se vê. Só se ouve o seu canto... (2007, p. 55).

Deus é uma suspeita do nosso coração de que o universo tem um coração que pulsa como o nosso. Suspeita.... Nenhuma certeza (2007, p. 55).

É preciso esquecer os nomes de Deus que as religiões inventaram para encontrá-lo sem nome no assombro da vida. Reverência pela vida: é a forma mais alta de oração. Sem nome.... O nome de Deus não pode ser pronunciado... (2007, p. 55).

A pergunta não deveria ser "Você acredita em Deus?", mas "Você se comove com a beleza?" Deus nunca foi visto por ninguém. Ele se mostra na experiência da beleza. [...] Deus é beleza (2007, p. 56).

Deus se comunica com os homens, fazendo-os sonhar (2007, p. 64).

Deus é como os olhos. Não podemos vê-lo para ver através dele. Deus é um jeito de ver (2007, p. 101).

Deus não se parece com os banqueiros. Ele não tem um livro de contabilidade. Deus não tem memória: nem pune pecados nem recompensa virtudes. 
É como um regato de águas cristalinas. Não importa que joguemos nele os nossos detritos. Ele continua a jorrar águas cristalinas (2007, p. 104).

Sei que desejas [Oh! Deus] dar-me o meu desejo mais fundo, desejo que esqueci.... Mas tu não esqueces nunca. Realiza, pois, o teu desejo, para que eu possa rir [Trecho da paráfrase do Pai Nosso] (2007, p. 154).

Deus não é objeto de pensamento. É objeto de degustação. Provai e vede que Deus tem gosto bom... Degustem esses aperitivos [os poemas sagrados] (2007, p. 159).

Beijava com sua sensibilidade comunicativa incansavelmente inovadora. Nisso fica sublinhado o conceito da liberdade poética. Mestre Benjamin sempre proferia seus ensinamentos a partir de pedidos e perguntas das pessoas, em especial das crianças mais curiosas. Isso é descrito no livro desde as primeiras páginas. Passando da metade, o escritor reconfigura o personagem. Depois que um menino the diz “queremos ouvir estórias que o Senhor das Estórias contou!" (2007, p. 101), a dinâmica é alterada. Não fica explícita uma eventual motivação na mudança de método do personagem. Simplesmente é anunciada - como convém aos caprichos dos anciãos em suas venerandas venetas: "Daquele dia em diante, Mestre Benjamin parou de esperar que lhe fizessem perguntas. Ele se assentava e a cada noite contava uma das parábolas do Senhor das Estórias" (2007, p. 109). Com efeito, nem todas as estórias daquele dia em diante eram parábolas do Senhor das Estórias. De qualquer modo, a escolha da primeira a ser contada-e-recriada parece sugestiva dessa mudança de método. O Benjamin rubeniano faz uma paráfrase inteiramente livre, deliciosa e instigante da parábola do bom samaritano (Lucas 10:30-37). A vítima é caracterizada como "um garçom que, depois de uma noite de trabalho, voltava para a sua casa com o pouco dinheiro que havia recebido como gorjetas para sustentar a sua família". O assalto acontece às "quatro horas da madrugada". Pela manhã, sem prestar ajuda ao garçom meio morto sobre a calçada, passa "por aquela rua, no seu carro, um sacerdote que se dirigia à igreja para celebrar a primeira missa”. Depois, um preconceituoso pastor evangélico também passa, comete um pseudoexorcismo e segue em seu carro para uma reunião de oração. Daí,

...levantado o sol, manhã clara, passava por ali um travesti, em sua lambreta, vindo de uma noite de farras. Ao ver o homem caído, o seu coração se comoveu. Parou, colocou o homem na garupa e levo-o a um hospital. Lá, tirou do seu bolso todo o dinheiro que tinha e disse: "Para pagar os gastos que houver...” E desapareceu antes que a polícia chegasse (2007, p. 109, 110). 
Primeiro detalhe curioso, literalmente marginal: a palavra lambreta é o aportuguesamento do italiano Lambretta, que por sua vez foi o nome dado por Ferdinando Innocenti (!!!) para a motoneta que inventou em sua fábrica localizada na região milanesa Lambratte. Este termo se refere ao rio Lambro (do latim, Lambrus; do grego Lamprus) que significa luzente, limpo (como sua água). ${ }^{15} \mathrm{Ou}$ seja, há uma conotação de pureza e inocência na história semântica da lambreta.

Segundo detalhe curioso, eroticamente marginal: o vocábulo garupa vem do frâncico kruppa (massa arredondada ${ }^{16}$ - boa apropriação verbal da icônica atrelagem do garçom às ancas do amável e solidário travesti. ${ }^{17}$

Terceiro detalhe curioso, biblicamente marginal: não sei se Rubem Alves chegou a ter conhecimento, mas uma ${ }^{18}$ travesti assim existe, de fato, em espírito e verdade, na cidade do Rio de Janeiro. Chama-se Luana Muniz. ${ }^{19}$

Beijava alterando palavras proferidas por Jesus, registradas em Lucas 18:9-14, e combinadas com outras encontradas em Mateus 21:31. Benjamin reconta a parábola do fariseu e do publicano, substituindo esse impopular e execrado coletor de impostos por "uma meretriz que ganhava o seu pão com a prostituição" (2007, p. 115). E conclui seu ensino sobre a graça (sobre a ousadia da graça) dizendo que "as prostitutas entrarão nos céus antes" de quem se gaba de sua santidade (2007, p. 116). Para essa conclusão, a forma como Benjamin descreve o fariseu e reelabora toda a parábola não segue rigorosamente a literalidade do texto evangélico. Benjamin/Rubem até usa com certa ironia esse advérbio (de modo) que formata o oposto ao tema que está em jogo (a graça): o fariseu "era homem de muitas posses e que observava rigorosamente todos os preceitos da sua religião" (2007, p. 115). Esse expediente literário de enfatizar e ignorar uma conduta hipócrita, farisaica,

15 Conforme consultas à Wikipédia, realizadas em fevereiro 2017: https://pt.wikipedia.org/ wiki/Lambretta; https://it.wikipedia.org/wiki/Lambro.

16 Conforme verbete no Dicionário Houaiss da Lingua Portuguesa.

17 Reproduzo aqui a grafia usada por Rubem Alves: do travesti, substantivo masculino (quando um homem se passa por mulher).

18 E agora deixo a regra já citada em favor de uma afirmação de transgênero.

19 Em matéria veiculada pelo programa televisivo da apresentadora Eliana no dia 27/03/2016 há uma entrevista com o Padre Fábio de Melo sobre alguns fatos e feitos da vida de Luana Muniz. Travesti, Rainha da Lapa, Rio de Janeiro, Luana atende moradores de rua. Mais detalhes podem ser conferidos nos endereços eletrônicos: https://www.youtube. com/watch?v=VURXLkQnJ6g e/ou https://www.youtube.com/watch?v=oeh8kJ-7xhY (íntegra da pregação do Padre Fábio de Melo, em 5/12/2015) (acessos em fev. 2017). 
trocando as palavras e as personagens é uma ousadia benjaminiano-rubeniana: ao se rebelar contra o rigor legalista, o autor rasga rigorosamente o rigor literal. Parece tal ousadia um posicionamento mais-que-simpático de resgate existencialista ao lado da "prostituta, [que] ao longe, não ousava nem mesmo levantar os seus olhos aos céus" (2007, p. 116). Aqui Mestre Benjamin dá uma aula magna sobre como aplicar o conceito da prevalência da graça no relato e na escrituração do sagrado.

Beijava criando uma parábola a partir de outra parábola. E mais: não apenas uma parábola; também a explicação da mesma, à moda dos evangelhos, porém, muito mais focado no sentido último que Benjamin/Rubem acreditava. A parábola original está no capítulo 13, versículos 45 (e seguinte) do evangelho segundo Mateus: "O reino dos céus é ainda semelhante a um negociante que anda em busca de pérolas finas. Ao achar uma pérola de grande valor, vai, vende tudo o que possui e a compra". ${ }^{20}$ Essa tão curta parábola é reescrita com muito mais elementos, preenchendo duas páginas do livro. E aqui transcrevo apenas meia dúzia de linhas: "Mas aquela joia, uma pérola, falava dos mistérios do mar. E, ao olhar para ela, ele se sentiu transportado para a sua infância, à beira mar [...]. Saiu ele então, vendeu todas as suas joias, muitas, e comprou aquela pérola, única. E o seu coração descansou..." (2007, p. 135,136). Após esse fechamento narrativo, alguém pede a Benjamin uma explicação da parábola. Então, o Senhor das Estórias responde, fazendo uma comparação entre pérola e mulher. E no contexto do relacionamento homem/mulher, o autor distingue o prazer da alegria. O prazer pode ser experimentado com muitas mulheres e amantes; porém a alegria, "de repente, por razões inexplicáveis", é vivida com aquela mulher que o coração do homem, descansado, garante que sua "busca chegou ao fim". Nesse caso, metaforicamente, a preciosidade da pérola (mulher) tem um custo existencial elevado, sublime; um custo surpreendente e inimaginavelmente sobre-humano; um custo que arrebenta as cercas das conveniências apaziguadoras. Não é um amor, é o amor. E os amantes acabam pagando com a própria vida a conquista-e-a-perda dessa alegria. Com isso Benjamin expõe um conceito não só de maneira explícita como, provavelmente, cifrada, camuflada e premonitória. Trata-se do conceito do mo(vi)mento de te(n)são diante do tamanho absurdo e absoluto do desejo. Tragédia. Abelardo e Heloisa. Rubem e Thais no Mar de Minas $^{21}$ com sua pérola sideral (pérola do

\footnotetext{
20 Mateus 13:45-46. Versão A Bíblia de Jerusalém.

21 Mar de Minas foi o nome dado por Rubem ao sítio dele e de Thais na região do vale da Pedra Branca (como uma pérola) em Pocinhos do Rio Verde, Caldas (MG), em 1996. Esse nome veio de uma canção composta por um amigo de Rubem, Ivan Vilella: https://www. youtube.com/watch?v= JEczZqQyZY (acesso em fev. 2017).
} 
desejo, la perla del desiderio). Nesse sítio, Mar de Minas, Rubem foi transportado para sua infância. Lá um balanço suspenso em caquizeiro serviu para infinitas estripulias do mineirinho sexagenário. Em testemunho, Carlos Rodrigues Brandão, amigo de Rubem por décadas, “afirmou, convicto, que o 'melhor Rubem Alves' que conheceu era aquele de Caldas. Porque lá ele ficava mais feliz e mais em paz" (GONÇALO JUNIOR, 2015, p. 328). E as palavras de Thais escritas em lágrimas para o amado Rubem em 6 de abril de 2013 (então separados, desde 2009) têm a eloquência absoluta e absurda do inolvidável vivido no Mar de Minas anos antes: "Procuramos pitangas no fundo de um riacho durante uma calma tarde, assistimos o balé das borboletas na cachoeira dos duendes, nadamos nus, sem vergonha e sem medo, sensação tão própria das crianças, daquelas que ainda não entenderam o que é proibido" (GONÇALO JUNIOR, 2015, p. 432). E pouco antes de completar 80 anos, Rubem, já bastante debilitado por causa do mal de Parkinson, envia nova mensagem de amor para Thais, transcrevendo (como se dele fossem) as palavras do poeta russo Alexander Pushkin:

\section{Eu te amei}

$e$ ainda te amo muito.

Mas esquece esse amor que tão tristemente

foi comprimido contra a tua vontade.

Eu te amei em silêncio

sem esperança, mas em verdade,

com ciúmes, com medo...

Eu rezo para que alguém

possa te amar de novo do mesmo jeito...

GONÇALO JUNIOR, 2015, p. 435).

\section{Ocaso de um caso de amor}

Nesse livro parece que Rubem Alves cria o personagem Benjamin e é por ele devorado. No último parágrafo da obra (...ou, na última garfada grafada), fica a marca dessa fada sobre esse fado..., fica esse jeito benjaminiano-rubeniano de escrever sobre o amor fati.

Enterraram Mestre Benjamin no alto de uma colina. De lá se veem montanhas no horizonte distante. Ao lado de sua sepultura plantaram uma árvore. Dizem que ainda não parou de crescer. Amarraram balanços nos seus galhos fortes e as crianças se divertem brincando de tocar as nuvens com a ponta dos pés. Escreveram-lhe como epitáfio as palavras do poeta Robert Frost: "Ele teve um caso de amor com a vida" (2007, p. 172-173). 
Também aqui Rubem Alves exerce a liberdade de expressão sobremodo criativa. O poema em tela é "Lição pra hoje", de Robert Frost, que termina com esses versos indicativos de determinações, desejos: “E se um epitáfio pudesse contar minha vida./ Teria um bem curto, pronto/ Para grafar em minha tumba:/ "Ele teve uma briga de amor com o mundo"' (Tradução livre do autor). ${ }^{22}$ Portanto, embora o último verso faça referência a uma briga de amor com o mundo, Rubem Alves modificou seus termos para "ele teve um caso de amor com o mundo", conforme uma publicação de 1998, Concerto para corpo e alma, p. 116. E posteriormente, o próprio Rubem em inúmeras oportunidades explicitou que gostaria de também ter esse epitáfio em sua lápide, com outra ligeira e importante alteração - a mesma que destinou a seu Benjamin: "Ele teve um caso de amor com a vida" (GONÇALO JUNIOR, 2015, p. 453).

Sete anos após a morte de Benjamin, chegou a vez de Rubem Alves (19 de julho de 2014). Não teve lápide. Foi cremado. Afinal, literatura não deve ser interpretada ao pé da letra.

E termino lembrando outro poeta, também amado por Rubem, que lançou no Brasil, em 2016, uma coletânea de poemas que seriam, eu aposto, apreciados e citados pelo Mestre do Benjamin. Degustei esse livro com minha esposa Nadia Regina nas folgas da produção deste artigo. Durante nossa leitura, muitas páginas lembraram o querido Rubão; algumas literalmente. E nessa quieta quarta-feira de cinzas de 2017, termino estas linhas - dedicadas a Raquel Alves e Thais Couto - transcrevendo a última página desse livro de Mia Couto:

\title{
Aprendiz de ausências
}

\author{
Morrer \\ como quem deságua sem mar \\ e, num derradeiro relance, \\ olha o mundo \\ como se ainda o pudesse amar.
}

\footnotetext{
22 No original, esse trecho do poema "The lesson for today": "And were an epitaph to be my story/ I'd have a short one ready for my own./ I would have written of me on my stone:/ I had a lover's quarrel with the world". Encontrei a íntegra do poema na internet, no endereço eletrônico https://ddink55.wordpress.com/2011/03/24/the-lesson-for-today/. A propósito, uma foto da lápide de Robert Frost, sepultado em Bennington, Vermont (USA), pode ser vista em http://www.davidpaulkirkpatrick.com/2013/03/22/robert-frosts-i-had-a-loversquarrel-with-the-world-from-the-lesson-for-today/ (acessos em fev. 2017).
} 


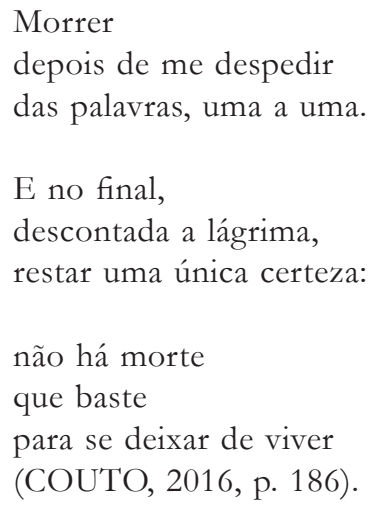

\section{Referências}

ALVES, Rubem. Concerto para corpo e alma. Campinas: Papirus Editora, 1998.

ALVES, Rubem. O quarto do mistério. Campinas: Papirus; Speculum, 1995.

ALVES, Rubem. Perguntaram-me se acredito em Deus. São Paulo: Editora Planeta, 2007.

BÍBLIA DE JERUSALÉM. São Paulo: Edições Paulinas, 1985.

CHALHUB, Samira. Funções da Linguagem. São Paulo: Ática, 1990.

COUTO, Mia. Poemas escolhidos. São Paulo: Companhia das Letras, 2016.

DELAS, Daniel \& FILLIOLET, Jacques. Linguística e Poética. São Paulo: Cultrix, 1975.

GONÇALO JÚNIOR. É uma pena não viver - uma biografia de Rubem Alves. São Paulo:

Planeta do Brasil, 2015.

HOUAISS, Antônio \& VILLAR, Mauro de Salles. Dicionário Houaiss da Língua

Portuguesa. Rio de Janeiro: Objetiva, 2001.

JAKOBSON, Roman. Linguística e Comunicação. São Paulo: Cultrix, 1969.

NIETZSCHE, Friedrich. Assim falava Zaratustra. Petrópolis: Editora Vozes, 2009.

\section{Sites consultados}

http://clinicalane.com.br/clinica.php

http:/ /www.davidpaulkirkpatrick.com/2013/03/22/robert-frosts-i-had-a-lovers-quarrel-withthe-world-from-the-lesson-for-today/

http://www.institutorubemalves.org.br

https://ddink55.wordpress.com/2011/03/24/the-lesson-for-today/ 
https://it.wikipedia.org/wiki/Lambro.

https://pt.wikipedia.org/wiki/Lambretta

https://www.youtube.com/watch?v=_JEczZqQyZY

https://www.youtube.com/watch?v=nRNmIumFui8

https://www.youtube.com/watch?v $=$ oeh8kJ-7xhY

https://www.youtube.com/watch?v=VURXLkQnJ6g

https://www.youtube.com/watch?v=xjJB3rHK9PE

Submetido em: 09-03-2017

Aceito em: 18-7-2017 